\title{
金属パラジウム触媒による各種アルコール類の 気相における酸化的エステル化反応
}

\author{
（1972 年 4 月 10 日受理）
}

功刀泰碩・河野哲夫・柳沢 賦・荒.井弘通*

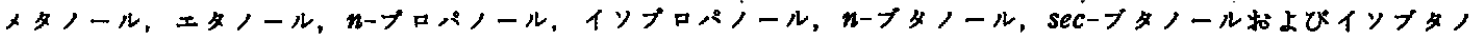

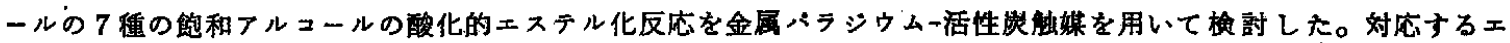
ステル,フルデヒドまだ岒ケンが得られた。

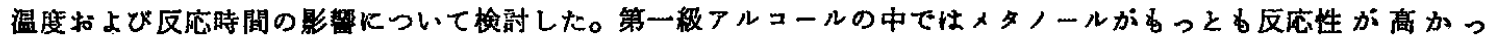

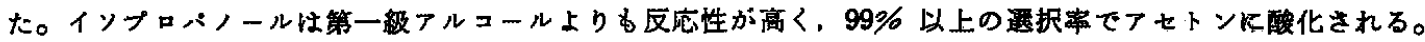
フルコールよりフルデヒドの生成の活性化エネルギーはメタノールおよびイソブタノールでは約 $13: 6 \mathrm{kcal} / \mathrm{mol} て ゙$ あり, 他のフルコールで汒 7.6〜7.8 kcal/mol であった。酸化的脱カルボニル化反枿と酸化的ェステル化反応の活性 化エネルギーの差は $7.8 \sim 8.8 \mathrm{kcal} / \mathrm{mol}$ であった。これらの結果はこれらの反応が以前報告したアセトアルデヒドと イソプロパノールの反応と同じ径路を通って反忘していることを示している。
\end{abstract}

\section{1 粕 镸}

気相でェタノールと酸素を金属パラジウム触媒を用いて反応さ せると酢酸エチルが選択率よく得られることはすで報告じ だ。さらにエタイールのかわうに炭素数 4 までの飽和アルコー ルを用いて同じ条件で検討したところ，アルコールが酸化脱水来 されて対応するエステル，アルデヒド，ケトンなとが生成するこ とが見いだされたので，その結果について報告する。

\section{2 実験}

\section{1 㝢験装㗨および操作}

実験装置怙よび操作は既報》のののと同じである。分析はすべ てガスクロマトグラフによった。すなわちガス状生成物のうち， 酸素, 窒素, メタン, 二酸化炭素, エタン, エチレンはモレキュ ラーシーブ5A 怙よびシリカゲルを充テンしたカラムを用い，プ ロパンおよびプロピレンは活性アルミナを充テンしたカラムを用 いて分析した。液状生成物はすべてジノニルフタレートを固定相 液体としたカラムを用いて分析した。キャリヤーガスはヘリウム を用いた。

\section{2 試 薬}

酸素，窒素は市肘ボンベ品を乾嬠剤で乾燥して用いた。アルコ 一ルはすべて関東化学株式会社から戝入した等級品を用いた。

\section{3 実矣条件および結果の整理方法}

実験は種々のアルコールにつき温度のみを変化させ他の因子は つぎのように一定にして行なった。

a）触媒：日本エンゲルハルド社製，0.5 wt\%パラシシウム・

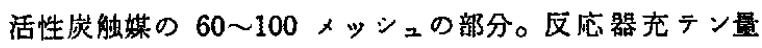
$0.500 \pm 0.005 \mathrm{~g}$

1）この報文を“酸化的エステル化反応に関する研笙（第 5 報)”とする。

2）前報（第 4 報）, 功刀泰硕，河野哲夫，吉野浩樹，日化， 1972, 2265.

* 東京大学工学部合成化学科, 東京都文京区本郷

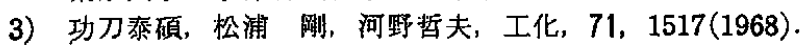

b ) 分止 : フルコール $0.40 \pm 0.03 \mathrm{~atm}$, 空気 $0.60 \pm 0.03 \mathrm{~atm}$

c) 原料供給量 : $0: 1 \mathrm{~mol} / \mathrm{hr}$

d) $W / F \quad 5 \pm 0.2 \mathrm{~g}-\mathrm{cat} \cdot \mathrm{hr} / \mathrm{g}-\mathrm{mol}$

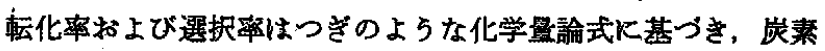
数基準で計算しだ。

$$
\begin{aligned}
& \mathrm{RCH}_{2} \mathrm{OH}+1 / 2 \mathrm{O}_{2} \longrightarrow \mathrm{RCHO}+\mathrm{H}_{2} \mathrm{O} \\
& \mathrm{RCHO}+\mathrm{RCH}_{2} \mathrm{OH}+\mathrm{I} / 2 \mathrm{O}_{2} \longrightarrow \mathrm{RCOOCH} \mathrm{H}_{2} \mathrm{R}+\mathrm{H}_{2} \mathrm{O} \\
& \mathrm{RCHO}+1 / 2 \mathrm{O}_{2} \longrightarrow \mathrm{RH}+\mathrm{CO}_{2} \\
& \mathrm{RCHO}+\mathrm{O}_{2} \longrightarrow \mathrm{R}^{\prime} \mathrm{H} \text { (Olefin) }+\mathrm{H}_{2} \mathrm{O}+\mathrm{CO}_{2}^{\prime} \\
& \mathrm{RCH}_{2} \mathrm{OH}+\mathrm{mO}_{2} \longrightarrow p \mathrm{CO}_{2}+q \mathrm{CO}_{2} \\
& \quad 3 \text { 結 果と考索 }
\end{aligned}
$$

\section{1 媒活性の経時変化}

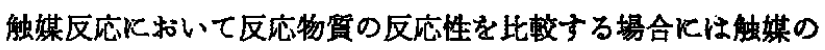
活性が安定していることが必要である。そこでメタノール, エタ ノール，n-プロパノールおよびイソブロパノールの反応における 活性の経時変化について椮討した。

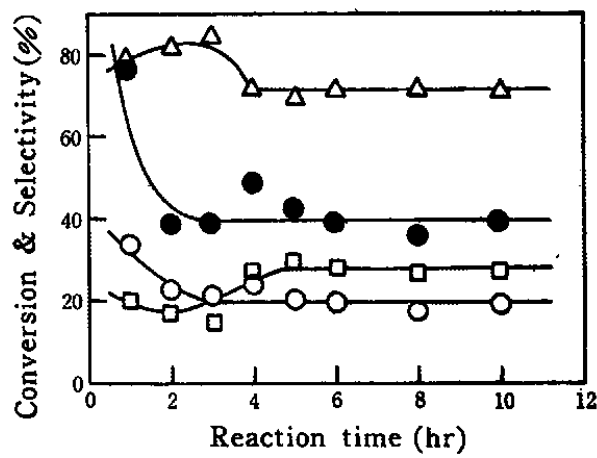

Fig. 1 Activity change of Pd catalyst in the oxidative esterification of methanol

Reaction temperature $: 80^{\circ} \mathrm{C}$

: Oxygen conversion, $O$ : Methanol conversion,

$\triangle:$ Methyl formate selectivity

$\square$ : Carbon dioxide selectivity 


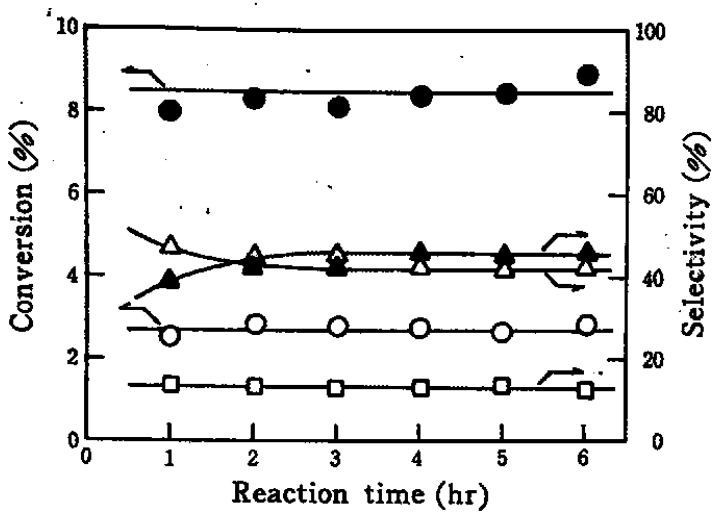

Fig. 2 Activity change of $\mathrm{Pd}$ catalyst in the oxidative esterification of $n$-propanol

Reaction temperature : $109^{\circ} \mathrm{C}$

: Oxygen conversion, $O: n$-Propanol conversion,

$\Delta$ : Propionaldehyde selectivity

$\triangle: n$-Propyl propionate selectivity

$\square$ : Carbon dioxide selectivity

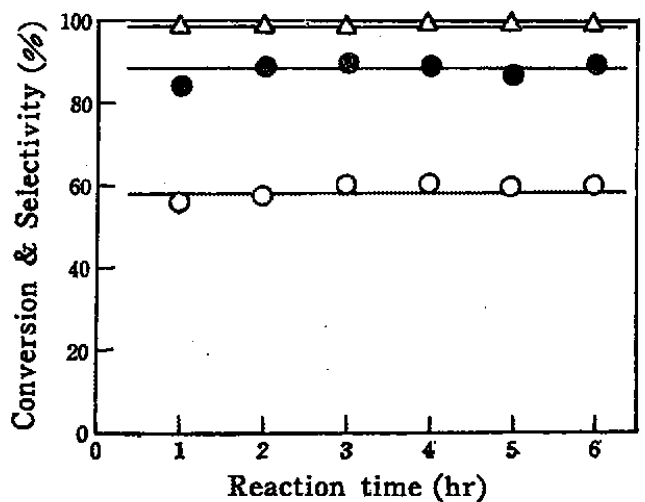

Fig. 3 Activity change of Pd catalyst in the oxidative esterification of $i$-propanol

Reaction temperature : $100^{\circ} \mathrm{C}$

: Oxygen conversion, $O: i$-Propanol conversion,

$\triangle:$ Acetone selectivity

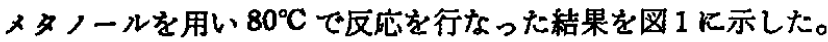
転化率壮 1 2 時間目飞急激に下がク，2 3 時間目以降定常値を 示すようになる。この他 $60^{\circ} \mathrm{C}$ で 24 時間, $80^{\circ} \mathrm{C}$ で 18 時間反成 を行なったところ，いずれる反応開始後 3〜4 時間で定常活性を 示した。

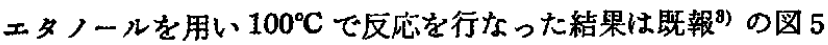
とほとんと同しで゙,ェタノール，酸素の転化率，生成物の選択率 とる 4 6 時間で一定となっている。nープロパノールを用い $109^{\circ} \mathrm{C}$ で応を行なった結果を図 2 K，イソブロパノールを用い $100^{\circ} \mathrm{C}$ で反応を行なった結果を図 3 K示した。いずれす短時間に 触媒が定常活性を示すよらになる。なおブタノール類については 検討しなかったが，以上の実験結果から定常活性を示すことは疑 いない。

\section{2 反応温度の影響}

メタノールを用いた反応結果を図 4 亿示した。反応温度の上昇 とともに酸素の転化率は增すけれとるメタノールのそれは $90^{\circ} \mathrm{C}$ 以上でせしろ減少する。これは反応ガス中の残仔酸菜が少ないこ と，拉よび酸素が生成したホルムアルデヒドの酸化分解㗹先的

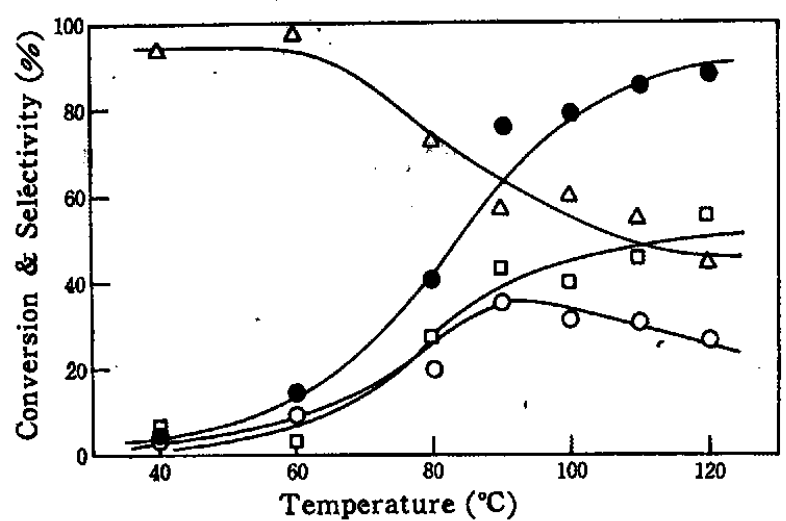

Fig. 4 Effect of temperature on the oxidative esterification of methanol

: Oxygen conversion, $O:$ Methanol conversion,

$\triangle:$ Methyl formate selectivity

$\square$ : Carbon dioxide selectivity

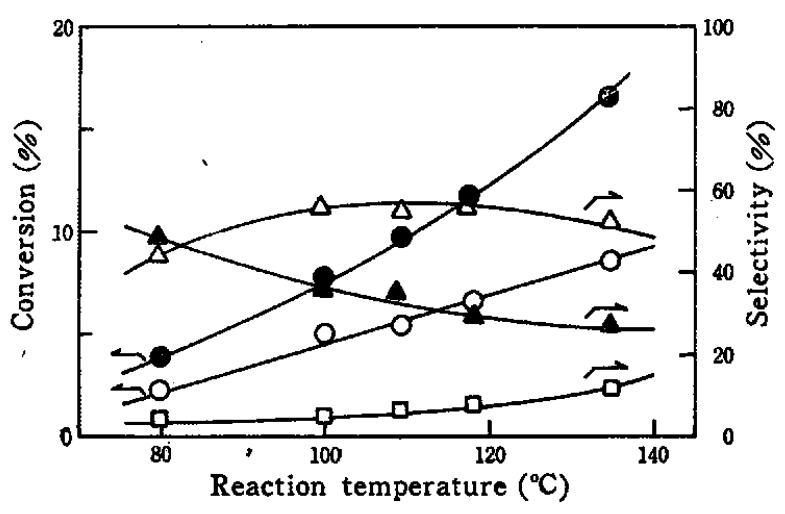

Fig. 5 Effect of temperature on the oxidative esterification of ethanol

: Oxygen conversion, $O$ : Ethanol conversion,

$\Delta$ : Acetaldehyde selectivity

$\triangle$ : Ethyl acetate selectivity, $\square:$ Methane selectivity

に使われることによる。キ酸メチルの選択率は $55^{\circ} \mathrm{C}$ 付近, 生成 量は $100^{\circ} \mathrm{C}$ 付近極大值をすつ。このことはキ酸メチルがホルム アルデヒド,メタノールおよび酸素から生成するが高温ではホル ムアルデヒドの酸化分解の反応速度が速くなることによると考え られる。二酸化炭素は選択率, 生成量とも反沁温度の上䒜にとす ない上昇する。な括 $144^{\circ} \mathrm{C}$ になると生成物は二酸化炭素のみとな りギ酸メチルはトレース量であった。

エタノールを用いた反応絬果を図5に示した。メタンと二酸化 炭素は等量生成していたので図にはメタンのみを示した。反応温 度の上界にともないエタノール，酸秦とむに転化率が增大する が，高温ではアセトアルデヒドの酸化分解がより起こりやすいの でメタノール同棁エステルの選択率は約 $110^{\circ} \mathrm{C}$ で極大値をもって いる。

クープロパノールを用いた反応結果を図6に示した。プロどオ ンアルデヒドの酸化分解生成物はェチレンと二酸化炭装である が，二酸化炭素の方がエチレン上り多い。な掠エタンントレース 量であった。エタノール, nーブタノールおよびイソブタノールの 場合には二酸化荻素は対応するアルデヒドの酸化分解によっての

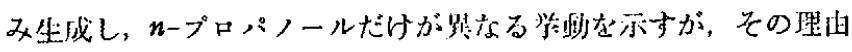
は明らかでない。 


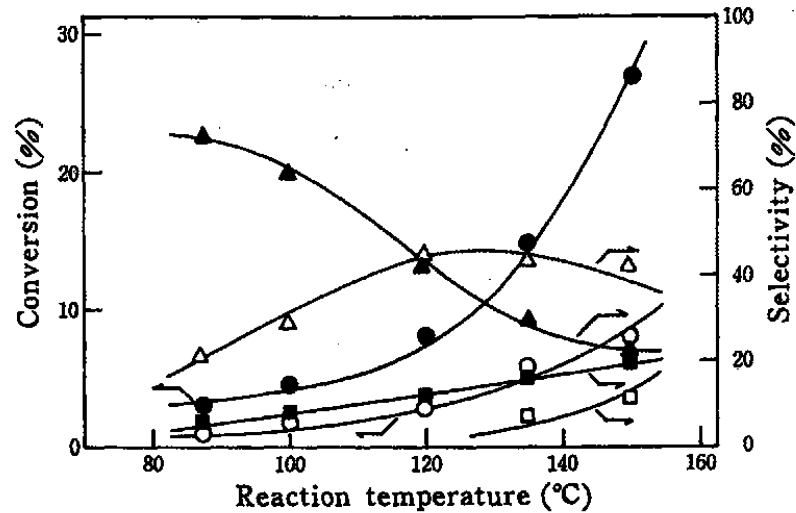

Fig. 6 Effect of temperature on the oxidative esterification of $n$-propanol

: Oxygen conversion, $\bigcirc: n$-Propanol conversion,

: Propionaldehyde selectivity

$\triangle:$ n-Propyl propionate selectivity

: Carbon dioxide selectivity, $\square$ : Ethylene selectivity

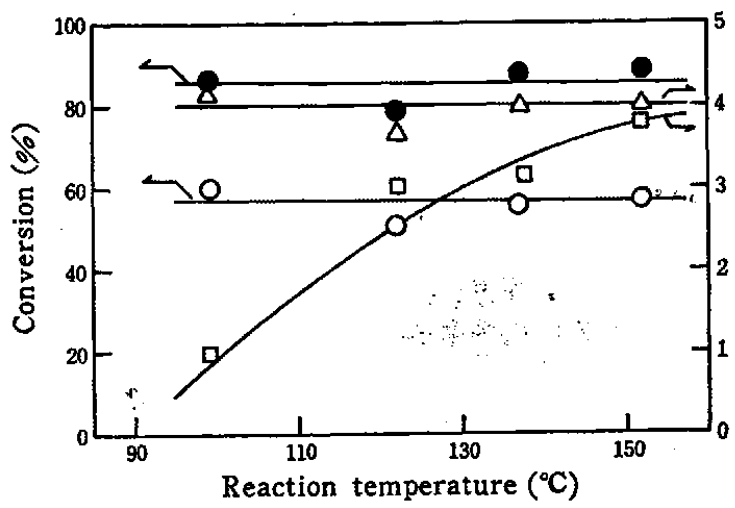

帝

Fig. 7 Effect of temperature on the oxidative esterification of $i$-propanol

: Oxygen conversion, $O: i$-Propanol conversion, $\triangle$ : Acetone, $\square:$ Carbon dioxide

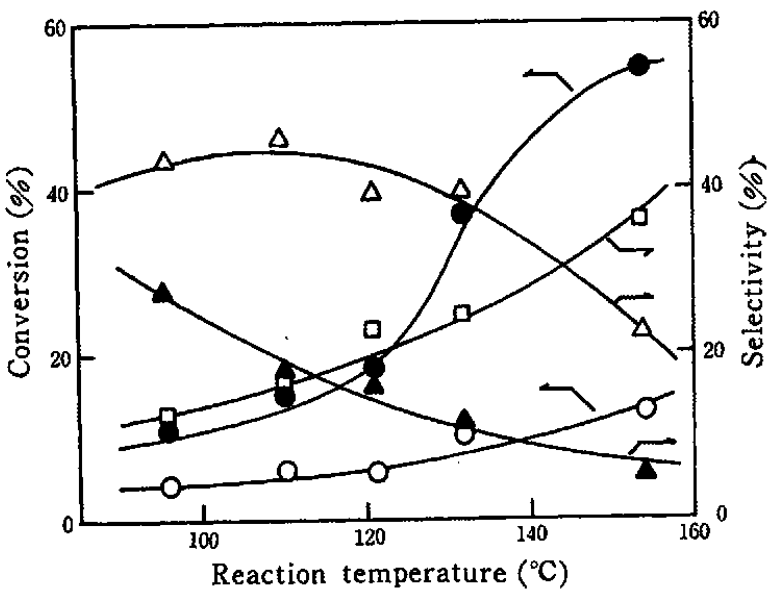

Fig. 8 Effect of temperature on the oxidative esterification of $n$-butanol

: Oxygen conversion, $O: n$-Butanol conversion, $\triangle: n$-Butyl $n$-butyrate selectivity

A : $n$-Butyraldehyde selectivity

$\square$ : Propylene selectivity

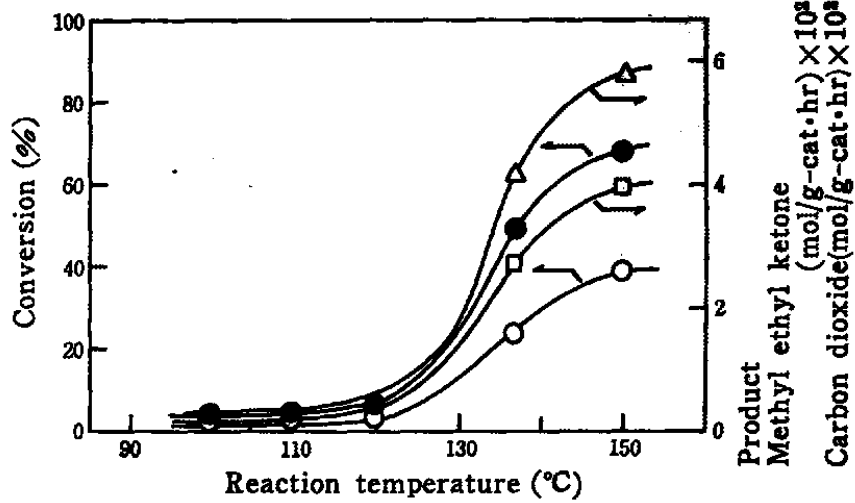

Fig. 9 Effect of temperature on the oxidative esterification of sec-butanol

: Oxygen conversion, $O$ : sec-Butanol conversion, $\triangle$ : Methyl ethyl ketone, $\square$ : Carbon dioxide

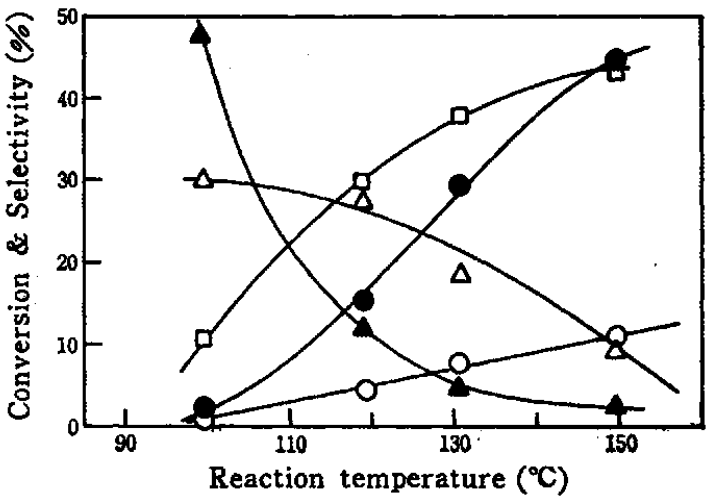

Fig. 10 Effect of temperature on the oxidative esterification of $i$-butanol

: Oxygen conversion, $O: i$-Butanol conversion,

$A$ : $i$-Butyl aldehyde selectivity

$\triangle: i$-Butyl $i$-butyrate selectivity

$\square$ : Propylene selectivity

イソブロパノールの反応結果を図7に示した。酸素イソブロパ ノールの転化率とす反応温度に対して一定となる。これはこの 反応の速度がきわめてはやく，かつ酸素が量論的に不足の実跧条 件であるため，この温度範聿では差がでてこないすのと考えられ る。

n-ブタノールの反応結果を図8に示した。 の選択率は $110^{\circ} \mathrm{C}$ 付近で極大值をすち，nーブチルアルデヒドの 選択率は反応温度の上昇にとるない減少する。これに対してブロ ピレンの選択率は急激に上昇している。nーブチルアルデヒドの酸 化分解によるプロ パンは微量であった。

sec-ブタノールの反応結果を図 9 に示した。これもインプロパ ノール同様酸化脱水素してヶトンを生じる。

イソブタノールの反芯結果を図 10 に示した。他のアルコール の場合にす反応温度の上昇とともにアルデヒドの選択率は減少す るがイソブキルアルデヒドの減少はとくにいちじるしい。イソブ チルアルデヒドの酸化分解の主生成物はブロピレンと二酸化炭莱 であり，副生成物としてアセトン拉よびプロ バンが生成する。ア セトンの生成はつぎの反応によると考えられる。

$$
\underset{\mathrm{CH}_{3}}{\mathrm{CH}_{3}}>\mathrm{CH}-\mathrm{CHO}+3 / 2 \mathrm{O}_{2} \longrightarrow \underset{\mathrm{CH}_{3}}{\mathrm{CH}_{3}}>\mathrm{CO}+\mathrm{CO}_{2}+\mathrm{H}_{2} \mathrm{O}
$$




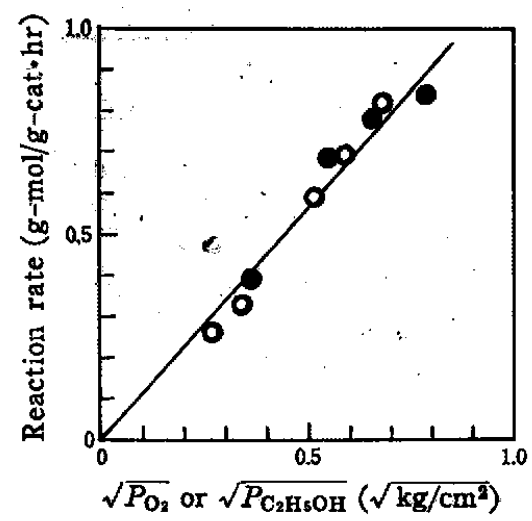

Fig. 11 Pressure dependency of reaction rate in the oxidative esterification of ethanol over $\mathrm{Pd}$ catalyst

$$
\begin{aligned}
& T=106^{\circ} \mathrm{C} \\
& O: r \text { vs. } \sqrt{P_{\mathrm{C}_{2} \mathrm{HsOH}}}, O: r \text { vs. } \sqrt{\mathrm{PO}_{2}}
\end{aligned}
$$

また副生成プロ パンの量は クーブタノールの揚合より少なかった。

\section{3 考 察}

3.3.1 アルテヒド生成反応の活性化エネルギー：本反応の径 路はつぎのよろと推定されているず。

$$
\begin{aligned}
& \mathrm{RCH}_{2} \mathrm{OH}+1 / 2 \mathrm{O}_{2} \longrightarrow \mathrm{RCHO}+\mathrm{H}_{2} \mathrm{O} \\
& \mathrm{RCHO}+\mathrm{RCH}_{2} \mathrm{OH}+1 / 2 \mathrm{O}_{2} \longrightarrow \mathrm{RCOOCH}_{2} \mathrm{R}+\mathrm{H}_{2} \mathrm{O}
\end{aligned}
$$

または

$$
\begin{aligned}
& \mathrm{RCHO}+1 / 2 \mathrm{O}_{2} \longrightarrow \mathrm{RH}+\mathrm{CO}_{2} \\
& \mathrm{RCHO}+\mathrm{O}_{2} \longrightarrow \mathrm{R}^{\prime} \mathrm{H} \text { (Olefin) }+\mathrm{H}_{2} \mathrm{O}+\mathrm{CO}_{2}
\end{aligned}
$$

（1）の反応仗より生成するアルデヒドの生成速度を $r_{1}$ とす る。エタノールを原料として反応を行なった結果名から酸素分圧 依存性和よびェタノール分压依存性を检討した。その結果を図 11 K示した。これからつぎの（4）の速度式が得られた。

$$
r_{1}=k_{1}\left[P_{\mathrm{O}_{2}}\right]^{1 / 2}\left[P_{\mathrm{C}_{2} \mathrm{HsOH}}\right]^{1 / 2}\left(r_{1}: \mathrm{mol} / \mathrm{g}-\mathrm{calt} \cdot \mathrm{hr}\right)
$$

この速度式から酸素関して解離吸着型の酸素が反応汇関与して いることがかかる。またエタノール関しては $1 / 2$ 次という反応 機構上考えにくいるのであるけれと，さらに検討したところこの エタノール分压の範囲では $P_{\mathrm{C}_{2} \mathrm{H}_{5} \mathrm{OH}} /\left(1+K P_{\mathrm{C}_{2} \mathrm{H}_{5} \mathrm{OH}}\right) \propto \sqrt{P_{\mathrm{C}_{2} \mathrm{H}_{5} \mathrm{OH}}}$ であることがわかった。したがってェタノールは活性点に樶着さ れて解離状の酸素と反応していることがわかりつざのような反 応機構が推定される。

$$
\begin{aligned}
& 2 \sigma+\mathrm{O}_{2} \longrightarrow 2 \sigma-0 \\
& \left.\sigma+\mathrm{ROH} \longrightarrow\left[\begin{array}{c}
\sigma \cdots \\
\dot{H} \\
\vdots
\end{array}\right] \rightarrow \mathrm{R}\right] \mathrm{H}-\sigma-\mathrm{OR} \\
& \sigma-\mathrm{O}+\mathrm{H}-\sigma-\mathrm{OR} \longrightarrow\left[\begin{array}{c}
0 \\
\sigma-0,-\mathrm{H}^{2}-\mathrm{C}^{-\sigma^{\prime}} \\
\mathrm{R}^{\prime}
\end{array}\right] \\
& \longrightarrow \mathrm{R}^{\prime}{\stackrel{\mathrm{C}}{C_{\mathrm{H}^{\prime}}^{\prime \prime}}}_{\sigma}^{\mathrm{O}}+\sigma \cdots \mathrm{O}_{\mathrm{H}}^{\prime \mathrm{H}} \longrightarrow \mathrm{R}^{\prime} \mathrm{CHO}+\mathrm{H}_{2} \mathrm{O}+\sigma
\end{aligned}
$$

この機構に打いて（7）式が律速と考劣れば求められた速度式 （4）と合致する。このような反応中間体括よび反応径路の推定 は Moiseev'), Uloyd ら5)が $\sigma-0$ のかわりの酸化削として Pd-X

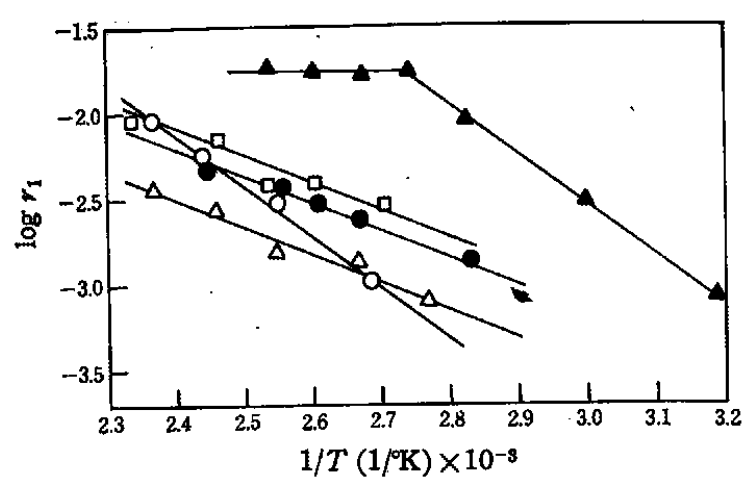

Fig. 12 Arrhenius plots of aldehyde formation reaction
$\Delta:$ Methanol, $O$ : Ethanol, $\triangle: n$-Propanol,
$\square: n$-Butanol, $\bigcirc: i$-Butanol

を考えていると見なせば同じすのとなる。

ここで（4）式を他のアルコールKついてす適用する。そこで 種々のアルコールルにつき平衡定数をす含んだ見かけの速度定数 $k_{1}$ を比較するため単位時間, 単位触媒量あたり生成したアルデヒド 量を次式にしたがい算出しこれを $r_{1}$ とした。

$$
\begin{aligned}
& r_{1}=\text { (生成アルデヒドのモル数) +(生成エステルのモル数) } \\
& \text { 十(生成オレフィン，パラフィンのモル数） }
\end{aligned}
$$

この $r_{1}$ の対数を $1 / T$ に対してプロットしたのが図12である。 この図からアルコールの反応性恃メタノールが一番よく，以下 nープタノール, エタノール, n-プロパノールの順となっている。 メタノール格よびイソブタノールからのアルデヒド生成の活性化 エネルギーはそれぞれ 13.6, $13.7 \mathrm{kcal} / \mathrm{mol}$ でほ注同じであり， 他方エタノール, n-プロ パノールおよび $n$-ブタノールの活性化 エネルギーはそれぞれ $7.8 ， 7.6,7.6 \mathrm{kcal} / \mathrm{mol}$ でこれらるはと んど同じである。このメタノール系とェタノール系の活性化エネ ルギー差の原因はアルコールの吸着平衡定数の温度依存性の差に よるものと考えられる。しかし活性化エネルギーに差はあるけれ と，すべてのアルコール炕いて (4) 式の温度依存性が直線で

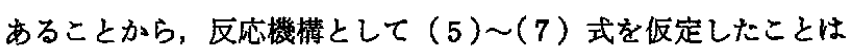
妥当である。

3.3.2 アルテヒドのエステル化およひ酸化分解の比較: イソ プロパノール (i-PrOH) とアセトアルデヒド $(\mathrm{AcH})$ の酸化的エ ステル化反応の速度諭的倹討の結果和から，エステル生成化つい ては（8）式，メタン生成については（9）式がそれぞれ近似的 に成立する。ただし $f_{2}, f_{3}$ はアルデヒドのみの関数である。

$$
\begin{aligned}
& \mathrm{d}(\text { Ester }) / \mathrm{d} t \doteqdot k_{2}\left[\mathrm{O}_{2}\right] f_{2}(\mathrm{AcH})[i-\mathrm{PrOH}]^{0} \\
& \mathrm{~d}\left(\mathrm{CH}_{4}\right) / \mathrm{d} t \fallingdotseq k_{8}\left[\mathrm{O}_{2}\right] f_{3}(\mathrm{AcH})[i-\mathrm{PrOH}]^{0}
\end{aligned}
$$

(8)，(9) 式から（10）式が導かれ，実験結果6)加得られた $f_{3}(\mathrm{AcH}) / f_{2}(\mathrm{AcH}) \doteqdot 7 / 26$ を代入して積分すると（11）式となる。

$$
\begin{aligned}
& \mathrm{d}\left(\mathrm{CH}_{4}\right) / \mathrm{d}(\text { Ester })=\left(k_{3} / k_{2}\right)\left(f_{9}(\mathrm{AcH}) / f(\mathrm{AcH})\right) \\
& \left(\mathrm{CH}_{4}\right) /(\text { Ester }) \fallingdotseq(7 / 26)\left(k_{3} / k_{2}\right)
\end{aligned}
$$

種々のアルコールにつき，アルコールと刘応するアルデヒドと のエステル化反応他ついては塩化パラジゥムー塩化銅を用いてア

4) I. I. Moiseev, et al., Zh.Cbsch.Khim, 33, 3239(1963).

5) W.G. Lloyd, J. Org. Chem., 32, 2816(1967).

6）功力泰碩，河野哲夫，工化，72，1282(1969). 
ルコールとアルデヒドの反応との類似性7，および液相における 反応結果8)の生成物から考兄（8）式を満たすと仮定できる。ま たアルデヒドの酸化分解反店については，生成物が従来の脱カル ボニル化反応㝵汇よる CO のかわりK $\mathrm{CO}_{2}$ であること以外は同 ビであることから，アセトアルデヒドの反応結果である（9）式 を満たすと仮定できる。

したがって（11）式を一般化して（12）式が得られる。 $E_{2} Ｅ_{8}$ はそれぞれ（2）（3）式の活性化エネルギーである。

$$
\begin{gathered}
\text { (Olefin) } /(\text { Ester })=\alpha\left(k_{3} / k_{2}\right)=\alpha\left(k_{3}{ }^{0} \exp \left(-E_{9} / R T\right) /\right. \\
\left.k_{2}{ }^{0} \exp \left(-E_{2} / R T\right)\right)=\beta \exp \left(-\left(E_{3}-E_{2}\right) / R T\right)
\end{gathered}
$$

この（12）式の左辺を1/Tに対してブロットしたものが四 13 で ある。罒から（12）式の $\left(E_{3}-E_{2}\right)$ が求まる。ホルムアルデと ド, アセトアルデヒド, ブロビオンアルデヒド, $n$ ーブチルアルデ ヒドではその差が $8.8 \sim 7.8 \mathrm{kcal} / \mathrm{mol}$ であり,イソプチルナルデ ヒドでは $13.6 \mathrm{kcal} / \mathrm{mol}$ である。第一級アルコールから生成する アルデヒドについては, アセトアルデヒドとイップロパノールの 反応における酸化分解反枕とエステル化反応の活性化エネルギー 差 $8.8 \mathrm{kcal} / \mathrm{mol}^{6)}$ とよい一致を示している。このことは（2）, （3）式の反応とす既報のよらな反応そデルにしたがっていると いえる。一方アアセトアルデヒドの場合にアルコールがエタノー ルでるイソブロパノールでる活性化エネルギーに大した差がない ことから，(2）と（3）の反応速度の差を決める因子はアルデヒ ドの構造であると考えられる。

3.3.3 第二級了ルコールの反応性について : イソプロ パノー ル, sec-プタノールは対応するケトンを考える。イソプロパノー ルからアセトンを生成する反応の速度は非常に速く, $100^{\circ} \mathrm{C}$ 以上 では温度依存性が諗められない。また secーブタノールにしてす $130^{\circ} \mathrm{C}$ 以上でかなり速く反応が進行する。これはアルコールから 生成するアルデヒドとパラジゥム触媒との相互作用が強く，第一

7) I. C. I, Fr. P., 1,372,946(1964).

8）功刀泰碩，河野哲夫，篠原善之，日化，投稿中.

9）たとえば, C. W. Bird, “Transition Metal Intermediates in Organic Synthesis", Logos Press (1967) p. 239.

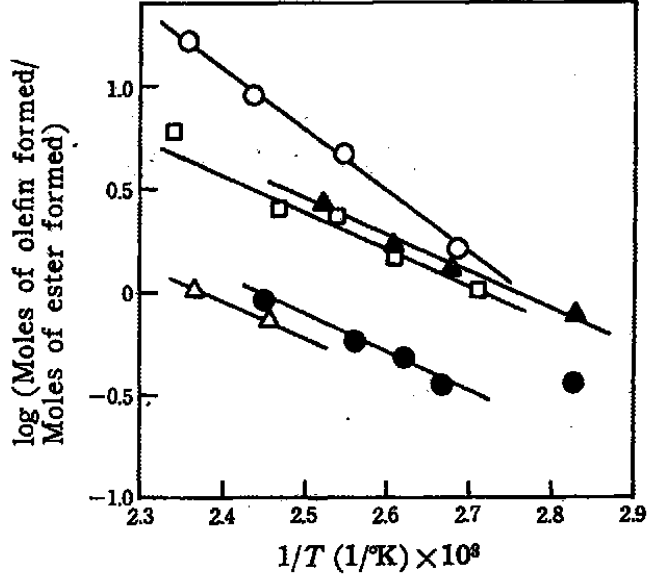

Fig. 13 Comparison of esterification reaction rate with oxidative decarbonylation reaction rate

$\mathrm{O}: \boldsymbol{i}$-Butyl aldehyde, : Acetaldehyde,

$\Delta:$ Formaldehyde, $\triangle: n$-Propion aldehyde,

$\square$ : n-Butyraldehyde

級アルコールの場合にはあたかる反応性が低いようにみえるため と考觉られる。このことは液相におけるアルデヒドとアルコール の反応結果とる一致するし，気相反応においてアルデとドが存在 するとその反応速度が大きく低下する゙)ことから考えてる妥当で ある。

\section{4 結 論}

以上の結果を要約するとつぎのようになる。

1）パラジウム触媒は酸化的エステル化反応において十分な活 性を長時間持続する。

2）パラジウム触媒を用いると第一級アルコールから対応する エステル, アルデヒド, アルデヒドの酸化分解物が得られる。

3）第二級アルコールから対応するケトンが 95\%以上の選択 率で得られる。

4）第一級アルコールの反応性についてはメタノールがとくに 高く，他のアルコール間ではそれほど羑がない。

\section{Gas Phase Oxidative Esterification Reaction of Various Alcohols over Metallic Palladium Catalyst ${ }^{\dagger}$}

Taiseki Kunugi, Tetsuo Kono, Mitsugu Yanagisawa and Hiromichi AraI

Department of Synthetic Chemistry, Faculty of Engineering, University of Tokyo; Hongo, Bunkyo-ku, Tokyo, Japan

Oxidative esterification of seven saturated alcohols, namely, methanol, ethanol, $n$-propanol, $i$-propanol, $n$-butanol, sec-butanol, and $i$-butanol was investigated over metallic palladiumactive charcoal catalyst. Corresponding ester, aldehyde or ketone is formed.

The effect of temperature and reaction time were examined. Methanol gives the highest reactivity among primary alcohols. $i$-Propanol shows remarkably higher reactivity than any primary alcohol and is oxidized to acetone with more than $99 \%$ selectivity.

The activation energies of aldehydes formation from alcohols are about $13.6 \mathrm{kcal} / \mathrm{mol}$ for methanol and $s e c-$ butanol and $7.6 \sim 7.8 \mathrm{kcal} / \mathrm{mol}$ for other alcohols. And the difference of the activation energy between oxidative decarbonylation reaction and oxidative esterification is about $7.8 \sim 8.8 \mathrm{kcal} / \mathrm{mol}$. These results suggest that these reactions occur via the same reaction path as that of acetaldehyde with $i$-propanol previously reported.

$\dagger$ Studies on Oxidative Esterification Reaction. V. 